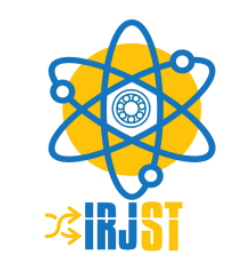

Available online at https://www.irjst.com/

International Research Journal of Science and Technology

ISSN:2707-3955

DOI: https://doi.org/10.46378/irjst.2020.010210

\title{
Analysis of the Contribution of China's Industrial Policies to Agriculture Sector
}

\section{Nuhu A. Sansa \\ Guangxi University, Nanning China}

\begin{tabular}{lll}
\multicolumn{2}{l}{ Paper Status } & \\
\hline Received & $:$ & January 2020 \\
Accepted & $:$ & March 2020 \\
Published & $:$ & March 2020
\end{tabular}

Key Words

Agriculture Sector

China Industrial Policies

Contribution.

\begin{abstract}
Recent different literature argued that China's agriculture sector contribution to economic development is deteriorating. The agriculture sector contribution with regard to Agriculture GDP contribution, agriculture employment, and foreign exchange earnings were decreased. The present study is undertaken to investigate the contribution of industrial policies to the Agriculture sector of China during the period from 2007 to 2018. Simple regression model employed as a methodology to investigate the contribution of industrial policies to the agriculture sector in China during the period from 2007 to 2018. The data of all agriculture macro-economic variables applied in this study (Economic openness, Agriculture GDP, Agriculture Food Production, and Employment in Agriculture) were collected from the World Bank for the whole period from 2007 to 2018. In order to investigate the contribution of Industrial policies to the agriculture sector in China, industrial policies were represented by the economic openness which stands as independent variable, while agriculture GDP, Agriculture food production and employment in agriculture were dependent variables in the study. The information discovered in the study was in actual fact catching the attention. Information discovered as a result of the investigation shows that relationship between Economic openness and Agriculture GDP is Negative, While the relationship between economic openness and other Agriculture macro-economic variables (Agriculture Food Production and Agriculture Employment) is Positive and meaningfully during the period from 2009 to 2018 in China. That means Industrial policies had meaningful contribution to Agriculture Food production and Agriculture Employment, While Industrial policies had no contribution to Agriculture GDP during the period from 2009 to 2018 in China.
\end{abstract}

Copyright (C) 2020: Nuhu A. Sansa. This is an open access distribution, and reproduction in any medium, provided Access article distributed under the Creative Commons Attribution License the original work is properly cited License, which permits unrestricted use.

Citation: Nuhu A. Sansa. “Analysis of the Contribution of China's Industrial Policies to Agriculture Sector”.International Research Journal of Science and Technology, 1 (2) 143-148, 2020.

\section{Introduction}

Industrial policies defined as government policies created to guide the manufacturing industry key aspects including production process, financing, marketing and selling of industrial produced goods purposely to achieve quickly and sustainable economic developments. Recent evidence shows that China's Industrial Policies play the vital role concerning quickly transforming of China's entire economy.

*Corresponding Author: Nuhu A. Sansa

Guangxi University, Economics Department, Nanning, China

Email : nuhusansa09@gmail.com
China industrialization journey take into account agriculture sector as the main backbone for the economic transformation.

China agriculture sector become the vital sector for China industrialization journey because it is the only sector produce raw materials which basically used by the industries to generate final goods for marketing and sales. From that regard, Industrial policies created to guide the agriculture sector must be given the special attention specifically how they are 
implemented, evaluated, and tested if the policies brought the desired goals within the required time.

China despite the fact that China's agriculture sector contribution to economic development is deteriorating, there is no studies have been done to investigate the contribution of China's industrial policies in the agriculture sector. The present study is undertaken to investigate the contribution of industrial policies to the agriculture sector in China. The study specifically directed to research the relationship between China's industrial policies and agriculture macro-economic variables which used by the study (agriculture GDP, Agriculture food production and employment in agriculture) during the period from 2007 to 2018

\subsection{Motivation of the Study and Objective}

Recent different literature argued that China's agriculture sector contribution to economic development is deteriorating. The agriculture sector contribution with regard to Agriculture GDP contribution, agriculture employment, and foreign exchange earnings were decreased. With reference to this fact, the present study is motivated to be undertaken to investigate the contribution of industrial policies to the agriculture sector in China during the period from 2007 to 2018.

The falling of the China's Agriculture contribution GDP were basically the results of the extension of the rest sectors differ from agriculture. In addition to that, it was also resulted from unfairly government agriculture policies in opposition to agriculture and curtailment on rural-urban population movement.To support the matter (Yao , 2000) argued that ,'First, although agriculture's share in GDP declined sharply over time, it is still an important force for the growth of other sectors. Second, the growth of nonagricultural sectors had little effect on agricultural growth. This was largely due to government policies biased against agriculture and restrictions on ruralurban migration".

The deterioration of China's agriculture sector contribution to economic development with regard to gross value added, employment, capital accumulation, urban welfare, and foreign exchange earnings were highlighted. FAO Report (1999), report the matter stating that, "Agriculture has made important, but declining contributions to national economic development in terms of gross value added, employment, capital accumulation, urban welfare, and foreign exchange earnings. Successive transformations of China's reform economy are based on economic growth in the agricultural sector. However, agriculture's role has declined. Before 1980, agriculture contributed more than 30 percent of GDP and half of export earnings. Each share fell below 20 percent by the early 1990s (Table 9). Agriculture employed 81 percent of labor in 1970, but only 50 percent in 1996. “'

China despite the fact that China's agriculture sector contribution to economic development is deteriorating, there is no studies have been done to investigate the contribution of China's industrial policies in the agriculture sector. The present study is undertaken to investigate the contribution of industrial policies to the agriculture sector in China. The study specifically directed to research the relationship between China's industrial policies and agriculture macro-economic variables which used by the study (agriculture GDP, Agriculture food production and employment in agriculture) during the period from 2007 to 2018.

\section{Objective of the Study}

The objective of the present study is to investigate the contribution of China's industrial policies to the agriculture sector, specifically agriculture macroeconomic variables used by the study (Agriculture GDP, Agriculture Food Production and Employment in Agriculture) during the period from 2007 to 2018 in China.

\section{Literature Review}

The expeditious thickening of China nonagricultural sectors contributed by enormous materials movement from agriculture. It was argued that, China has achieved spectacular growth since 1949. Rapid growth in the nonagricultural sectors has been assisted by massive resource transfers out of agriculture [1].

The deterioration of agriculture sector contribution to China's economic development emphasized by the FAO Report of 1999 [2]. The Report written that "Agriculture has made important, but declining contributions to national economic development in terms of gross value added, employment, capital accumulation, urban welfare, and foreign exchange earnings. Successive transformations of China's reform economy are based on economic growth in the agricultural sector. However, agriculture's role has declined. Before 1980, agriculture contributed more than 30 percent of GDP and half of export earnings. Each share fell below 20 percent by the early 1990s (Table 9). Agriculture employed 81 percent of labor in 1970, but only 50 percent in 1996" (FAO Report 1999) [2].

Agriculture remains the backbone of China's economy and the world at large; the significant question for discussion is how the population of China can be accommodated in terms of agriculture and food products demands. The matter stating that, 
"Agriculture has been the foundation of China's economy for centuries and remains vital for world sustainability [3]. There have always been "great debates" regarding China's agriculture development.

The most fundamental one is whether and how China can feed her large population. China has been struggling with this challenge throughout her long history and will continue to face it as the population grows and the country becomes increasingly affluent. Furthermore, the ongoing processes of rapid economic growth and urbanization not only bring great opportunities but also new challenges to agriculture and rural society. There have been new concerns in various areas, such as food safety, agricultural nonpoint source pollution, etc"[3].

China's industrial revolution, which started 35 years ago, is perhaps one of the most important economic and geopolitical phenomena since the original Industrial Revolution 250 years ago. The reason is simple: Less than 10 percent of the world's population is fully industrialized; if China can successfully finish its industrialization, an additional 20 percent of the world's population will be entering modern times [4]. China's transformation from a sleeping rural, agricultural giant to manufacturing and service sector kingpin had brought rapid infrastructure development, urbanization, rising per capita income and a big shift in the composition of its GDP [5].

Agricultural production over the period from 1978 to 2012 demonstrated a pattern of stable growth, much due to the impact of economic reform in rural areas and changes in government policies towards agricultural production and farmers' wellbeing [6]. China's state sector reform process is examined through the key sector of agriculture. A preview of aggregate statistics and broader reform measures indicate the declining role of the state [7].

We see industrialization in China the last 150 years as an ongoing process through which firms acquired and deepened manufacturing capabilities. Two factors have been consistently important to this process: openness to the international economy and domestic market liberalization [8].

From 1978 to 2008, China's economy grew at an average of $9.8 \%$ while its poverty incidence decreased from $63 \%$ to $10 \%$. According to $\mathrm{Li}$, this success was largely driven by growth in smallholder farming. In fact, agricultural growth was responsible for $35 \%$ of China's overall GDP growth and contributed four times more to poverty reduction than all of China's manufacturing services combined [9]. This suggests that programmes which increase the productivity of agriculture may also benefit the wider economy, and that an 'agriculture first' development strategy could be more effective than previously thought [10].

\section{Data and Methodology}

The present study is undertaken to investigate the contribution of industrial policies to the Agriculture sector of China during the period from 2009 to 2018. Simple regression model in Double Log and Semi Log Linear Models employed as a methodology to investigate the contribution of industrial policies to the agriculture sector in China during the period from 2009 to 2018. The data of all agriculture macroeconomic variables applied in this study (Economic openness, Agriculture GDP, Agriculture Food Production, and Employment in Agriculture) were collected from the World Bank for the whole period from 2009 to 2018. In order to investigate the contribution of Industrial policies to the agriculture sector in China, industrial policies were represented by the economic openness which stands as independent variable, while agriculture GDP, Agriculture food production and employment in agriculture were dependent variables in the study.

To analyses the contribution of industrial policies to the agriculture sector, the study bring into existence the following equation:

The Contribution of industrial policies to China Agriculture GDP:

$\mathrm{ChnAgGdp}=\mathrm{A}+\mathrm{M}+\mathrm{B} 1$.

Where, ChnAgGdp is the natural log for China Agriculture GDP, M is Economic Openness Index, A is Constant, and B1 is Coefficient Parameter.

The Contribution of industrial policies to China Agriculture Food Production:

ChnAgFood $=\mathrm{A}+\mathrm{M}+\mathrm{B} 1 \ldots \ldots \ldots \ldots \ldots \ldots \ldots . .(1)$

Where, ChnAgFood is the natural log for China Agriculture Food Production, $\mathrm{M}$ is Economic Openness Index, A is Constant, and B1 is Coefficient Parameter.

The Contribution of industrial policies to China Agriculture Employment:

ChnAgEmpl $=\mathrm{A}+\mathrm{M}+\mathrm{B} 1$.

Where, ChnAgEmpl is the natural log for China Agriculture Employment, $\mathrm{M}$ is Economic Openness Index, A is Constant, and $\mathrm{B} 1$ is Coefficient Parameter.

\section{Results and Discussion}

The present study after gathering of the information required for testing, the study used Descriptive and Analytical Approach to explore the contribution of industrial policies to the agriculture sector in China during the period from 2009 to 2018. 


\subsection{Data}

Appendix 1. Original data from World Bank of Economic Openness Index and Agriculture Macroeconomic Indicators of China during the period from 2009 to 2018.

\begin{tabular}{lllllll}
\hline Y & EOI & CAG & FP & EM & EF & TM \\
\hline 2018 & 38.26 & 7.19 & 0 & 28.752 & 24.235 & 52.987 \\
2017 & 38.15 & 7.566 & 0 & 28.977 & 24.438 & 53.415 \\
2016 & 37.21 & 8.126 & 139.03 & 29.735 & 25.117 & 54.852 \\
2015 & 39.629 & 8.422 & 135.91 & 30.662 & 25.97 & 56.632 \\
2014 & 45.065 & 8.674 & 131.86 & 31.615 & 26.828 & 58.443 \\
2013 & 46.744 & 8.943 & 129.79 & 33.584 & 28.644 & 62.228 \\
2012 & 48.268 & 9.114 & 127.7 & 35.861 & 30.751 & 66.612 \\
2011 & 50.741 & 9.178 & 123.39 & 37.097 & 31.907 & 69.004 \\
2010 & 50.717 & 9.325 & 119.96 & 39.043 & 33.753 & 72.796 \\
2009 & 45.185 & 9.636 & 116.86 & 40.477 & 35.126 & 75.603 \\
Total & 439.9 & 86.174 & 1024.5 & 335.80 & 286.769 & 622.572 \\
\hline
\end{tabular}

Where by : Y is Year, EOI is Economic Openness Index, CAG is China Agriculture GDP, FP is Food Production Index, EM is Employment by Males in Agriculture , EF is employment by Female in Agriculture, TM is the Total employment(Male Plus Female).

\begin{tabular}{cllll} 
Appendix 2: Natural Logarithms Computations originated from Appendix & \multicolumn{1}{c}{ EOI } & CAG & FP & TM \\
\hline 2018 & 3.64 & 2.02 & 0 & 3.97 \\
2017 & 3.64 & 2.02 & 0 & 3.98 \\
2016 & 3.62 & 2.1 & 4.93 & 4 \\
2015 & 3.68 & 2.13 & 4.91 & 4.04 \\
2014 & 3.81 & 2.16 & 4.88 & 4.07 \\
2013 & 3.84 & 2.2 & 4.87 & 4.13 \\
2012 & 3.88 & 2.21 & 4.85 & 4.2 \\
2011 & 3.93 & 2.22 & 4.82 & 4.23 \\
2010 & 3.93 & 2.23 & 4.79 & 4.29 \\
2009 & 3.81 & 2.27 & 4.76 & 4.33 \\
Total & 37.78 & 21.56 & 38.81 & 41.24 \\
\hline
\end{tabular}

Where by : Y is Year, EOI is Economic Openness Index, CAG is China Agriculture GDP, FP is Food Production Index, EM is Employment by Males in Agriculture , EF is employment by Female in Agriculture, тM is the Total employment(Male Plus Female).

Table 1. Regression Outcome Between Economic Openness and Agriculture GDP during the period from 1996 to 2015 in China. (Dependent Variable : ChnAgrGdp)

\begin{tabular}{lllll}
\hline $\mathrm{V}$ & $\mathrm{CT}$ & $\mathrm{SD}$ & $\mathrm{T}$ & $\mathrm{P}$ \\
$\mathrm{M}$ & -3.4286 & 1.1538 & -2.9717 & 0 \\
$\mathrm{C}$ & 15.1093 & & & 0 \\
$\mathrm{R} 2$ & 23.5102 & & & \\
$\mathrm{AR}$ & 26.3238 & & & \\
S.E.R & 0.4317 & & & \\
NOB $=10$ & & & & \\
\hline
\end{tabular}

Origin: Approximated from Appendix 3 
Where by:

$\mathrm{V}$ is Variable, CT is Coefficient, $\mathrm{C}$ is Constant, SD is the Standard Deviation, T is T-Statistic, $\mathrm{P}$ is Probability, M is Economic Openness, R2 is R-Squared, AR is Adjusted R-Square, SER is Standard Error of Estimation NOB is number of Observation.

Appendix 3. Regression Calculations between Economic Openness Index and China Agriculture GDP during the period from 1999 to 2018. [ Figures originated from Appendix 2].

\begin{tabular}{llllll}
\hline $\mathrm{Y}$ & $\mathrm{EOI}$ & $\mathrm{CAG}$ & $\mathrm{X}^{2}$ & $\mathrm{Y}^{2}$ & $\mathrm{XY}$ \\
\hline 2018 & 3.64 & 2.02 & 13.2496 & 4.0804 & 7.3528 \\
2017 & 3.64 & 2.02 & 13.2496 & 4.0804 & 6.7872 \\
2016 & 3.62 & 2.1 & 13.1044 & 4.41 & 7.602 \\
2015 & 3.68 & 2.13 & 13.5424 & 4.5369 & 7.8384 \\
2014 & 3.81 & 2.16 & 14.5161 & 4.6656 & 8.2296 \\
2013 & 3.84 & 2.2 & 14.7456 & 4.84 & 8.448 \\
2012 & 3.88 & 2.21 & 15.0544 & 4.8841 & 8.5748 \\
2011 & 3.93 & 2.22 & 15.4449 & 4.9284 & 8.7246 \\
2010 & 3.93 & 2.23 & 15.4449 & 4.9729 & 8.7639 \\
2009 & 3.81 & 2.27 & 14.5161 & 5.1529 & 8.6487 \\
Total & 37.78 & 21.56 & 142.86 & 46.551 & 80.97 \\
\hline
\end{tabular}

Where by : $\mathrm{Y}$ is Year, EOI is Economic Openness, CAG is China Agriculture GDP, $\mathrm{X}^{2}$ is Economic Openness Index multiplied by Economic Openness, $\mathrm{Y}^{2}$ is China Agriculture GDP multiplied by China Agriculture GDP, and XY is Economic Openness multiplied by China Agriculture GDP.

Table 3. Regression Outcome between Economic Openness and Agriculture Employment during the period from 1996 to 2015 in China. (Dependent Variable : ChnAgrEmpl)

\begin{tabular}{lllll}
\hline $\mathrm{V}$ & $\mathrm{CT}$ & $\mathrm{SD}$ & $\mathrm{T}$ & $\mathrm{P}$ \\
\hline $\mathrm{M}$ & 0.9286 & 0.4532 & 2.04898 & 0 \\
$\mathrm{C}$ & 0.72 & & & 0 \\
$\mathrm{R} 2$ & 0.7544 & & & \\
$\mathrm{AR}$ & 0.7188 & & & \\
S.E.R & 0.1696 & & & \\
NOB $=10$ & & & & \\
\hline
\end{tabular}

Where by: $\mathrm{V}$ is Variable, CT is Coefficient is Constant, $\mathrm{SD}$ is the Standard Deviation, T is T-Statistic, P is Probability, $\mathrm{M}$ is Economic Openness, R2 is R-Squared, AR is Adjusted R-Square, SER is Standard Error of Estimation NOB is number of Observation.

\subsection{The contribution of industrial policies to agriculture GDP DURING the period from 2009 to 2008 in china.}

Information discovered as a result of the investigation shows that relationship between Economic openness and China Agriculture GDP during the period from 2009 to 2018 is Negative. The results show the multiplier of Economic Openness is -3.4286, which means the relationship between Economic openness and China Agriculture GDP is meaningless. Therefore
Industrial policies had no contribution to Agriculture GDP in China during the period from 2009 to 2018.

Appendix 5: Regression Calculations between Economic Openness Index and China Agriculture Employment during the period from 1999 to 2018.[ Figures originated from Appendix 2].

\begin{tabular}{llllll}
\hline YEAR & EOI & CAE & $\mathrm{X}^{2}$ & $\mathrm{Y}^{2}$ & $\mathrm{XY}$ \\
\hline 2018 & 3.64 & 3.97 & 13.2496 & 15.760 & 14.4508 \\
2017 & 3.64 & 3.98 & 13.249 & 15.840 & 14.4872 \\
2016 & 3.62 & 4 & 13.104 & 16 & 14.48 \\
2015 & 3.68 & 4.04 & 13.542 & 16.321 & 14.8672 \\
2014 & 3.81 & 4.07 & 14.516 & 16.564 & 15.5067 \\
2013 & 3.84 & 4.13 & 14.745 & 17.056 & 15.8592 \\
2012 & 3.88 & 4.2 & 15.054 & 17.64 & 16.296 \\
2011 & 3.93 & 4.23 & 15.444 & 17.892 & 16.6239 \\
2010 & 3.93 & 4.29 & 15.444 & 18.404 & 16.8597 \\
2009 & 3.81 & 4.33 & 14.516 & 18.748 & 16.4973 \\
TOTAL 37.78 & 41.24 & 142.86 & 170.23 & 155.928 \\
\hline
\end{tabular}

Where by : $\mathrm{Y}$ is Year, EOI is Economic Openness, CAE is China Agriculture Employment, $\mathrm{X}^{2}$ is Economic Openness Index multiplied by Economic Openness, $\mathrm{Y}^{2}$ is China Agriculture Employment multiplied by China Agriculture Employment, and XY is Economic Openness multiplied by China Agriculture Employment. 


\subsection{The Relationship between Industrial Policies and Agriculture Sector}

In order to investigate the contribution of Industrial policies to the agriculture sector in China, industrial policies were represented by the economic openness which stands as independent variable, while agriculture GDP, Agriculture food production and employment in agriculture were dependent variables in the study.

\section{Summary of the Findings}

Information discovered as a result of the investigation shows that relationship between Economic openness and Agriculture GDP is Negative, while the relationship between economic openness and other Agriculture macro-economic variables (Agriculture Food Production and Agriculture Employment) is Positive and meaningfully during the period from 2009 to 2018 in China. That means Industrial policies had meaningful contribution to Agriculture Food production and Agriculture Employment, While Industrial policies had no contribution to Agriculture GDP during the period from 2009 to 2018 in China.

\section{Conclusion}

The present study is undertaken to investigate the contribution of China's industrial policies to the agriculture sector, specifically agriculture macroeconomic variables used by the study (Agriculture GDP, Agriculture Food Production and Employment in Agriculture) during the period from 2007 to 2018 in China. The information discovered in the study was in actual fact catching the attention. The study discovered that there is a positive and significant relationship between Economic Openness and all agriculture macro-economic variables used by the study (agriculture GDP, agriculture food production and employment in agriculture) during the period from 2007 to 2018 in China. That means China's industrial policies had significant contribution to the agriculture sector during the period from 2007 to 2018 in China.

\section{Recommendation}

In order to create the modern, reliable, sustainable, and most important industrial policies which reflect the actual environment of agriculture sector in China, the study prefer to make the following recommendations:

Further research should be done concerning; "The making and unmaking of strong and weak policies, understanding policies features formation within agriculture sector in China".
In addition to that, other studies should be done to investigate; the making and unmaking of strong and weak policies, understanding policies features formation within the whole industrial sector in China". The proposed studies will create the understanding to the China government about the weak and strong industrial policies exist in agriculture sector and industry in general. With that understanding review of the industrial policies to make them strong, effective and efficiency will be easily achieved.

Due to the technological advancement and the coming of digital economy, Industrial policies should be reviewed to reflect support the digital economy mechanism in China. China Government should consider the complementary of industrial policies, investment policies and digital policies in a perspective of objectives and creating to achieve the desired goals of quickly economic transformation.

\section{References}

[1]. Shujie Yao (2000): How important is agriculture in China's Economic growth. Oxford development studies. Volume 28, 2000-Issue 1.

[2]. FAO Report (1999) : Poverty Alleviation and Food Security in Asia. Lessons and Challenges-Annex 3: Agricultural Policy and Food security In China.

[3]. Jialing $\mathrm{Yu}$ and Jian $\mathrm{Wu}$ (2018): The sustainability of agricultural development in China: The Agriculture environment Nexus. Sustainability MDPI.

[4]. Yi Wen (2016): China's Rapid rise: From Backward agrarian society to an industrial powerhouse in just 35 years. Federal Reserve Bank of ST. LOUIS.

[5]. Prableen Bajpai (2014): China's GDP Examined: A service sector surge.

[6]. Li Zhou (2013): China's: A new model for growth and development-(8). China's agricultural development and challenges.

[7]. Scott Waldron, Colin Brown and John Long Worth (2019): State sector reform and agriculture in China.

[8]. Loren Brandt, Debin Ma, Thomas Rawski (2016): Industrialization In China.

[9]. Development Cooperation Report (2015): How China's Agriculture Miracle Combines economic growth with poverty reduction.

[10]. Samuel Marden (2014). The agricultural roots of industrial development. World Economic Forum Annual Meeting. 